\title{
THE ROLE OF SOCIAL MEDIA BROWSING INTENTION FOR BEHAVIORAL OUTCOMES OF YOUNG CONSUMERS
}

\section{ULOGA NAMJERE PREGLEDAVANJA DRUŠTVENIH MEDIJA NA ISHODE PONAŠANJA MLADIH POTROŠAČA}
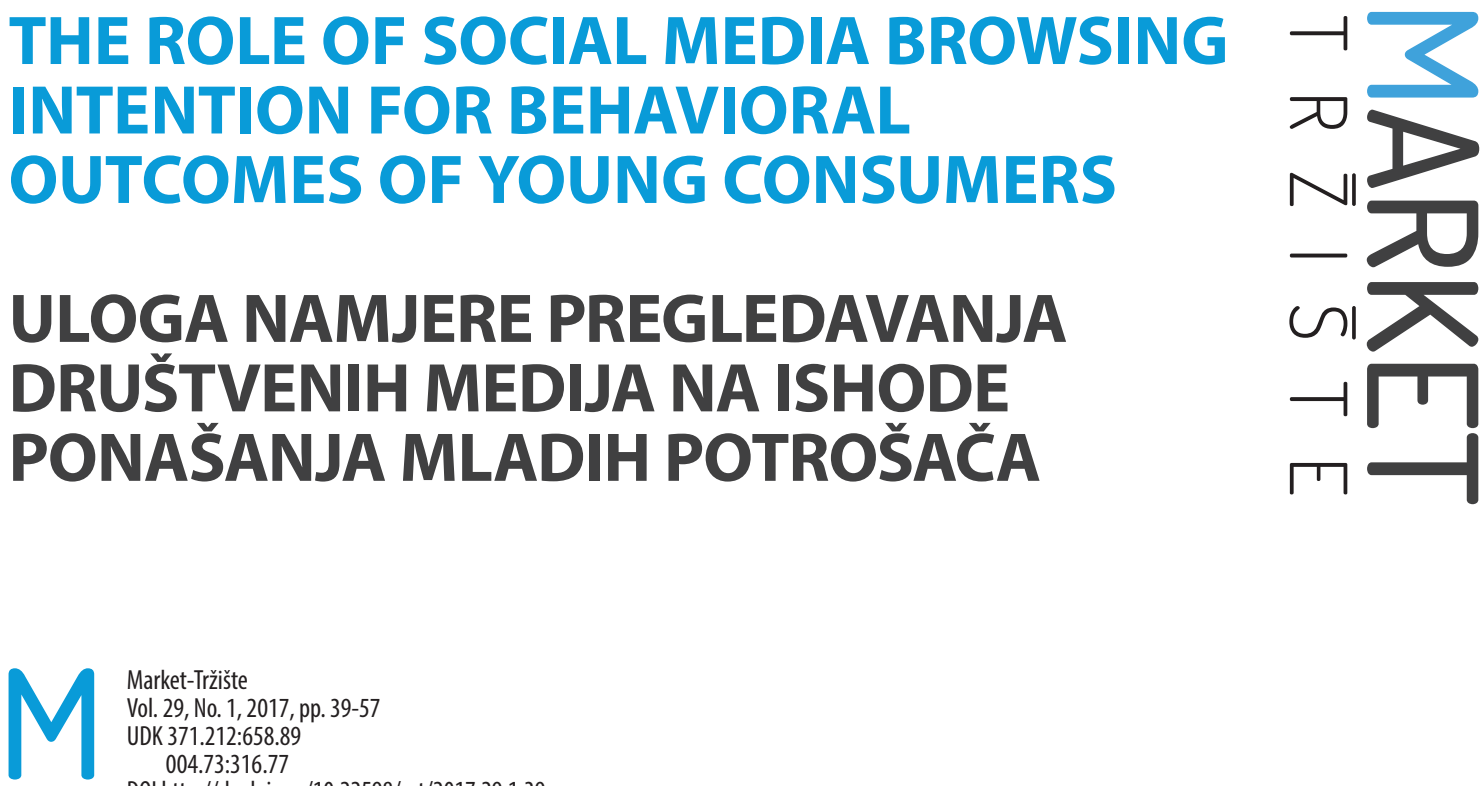

Market-Tržište

Vol. 29, No. 1, 2017, pp. 39-57

UDK 371.212:658.89

004.73:316.77

DOl http://dx.doi.org/10.22598/mt/2017.29.1.39

Preliminary communication

\footnotetext{
Pramono Hari Adia, Faizal Wihudab, Wiwiek Rabiatul Adawiyahc

a) Jenderal Soedirman University, Purwokerto, INDONESIA, pramonounsoed@gmail.com

b) Jenderal Soedirman University, Purwokerto, INDONESIA, faizalwihuda@gmail.com

c) Jenderal Soedirman University, Purwokerto, INDONESIA, wiwiekra@gmail.com
}

\begin{abstract}
Purpose - This research study attempts to analyze the online shopping orientation of high-school students through social media and the mediating effects of social media browsing intention on the relationship between shopping orientation and electronic word of mouth. The authors specifically investigated the effect of hypothesized variables, including hedonic and utilitarian motivation, social media browsing intention, word of mouth, and purchase intention.
\end{abstract}

Design/Methodology/Approach - Data were collected from senior high-school students. The total sample of 191 senior high-school students was used to test the research model. A conceptual model was proposed to illustrate the relationships between online shopping orientation and social media browsing intention, and how word of mouth influences purchase intention.

Findings and implications - Research results indicate that specific aspects of behavioral orientation, that is, utilitarian and hedonic motivations, have a significantly positive impact on user intention to browse products on social media. Social media browsing intention is linked in a significantly positive manner with word of mouth. Additionally, the mediation analysis approach showed that social media browsing intention mediates the relationship between online shopping orientation and electronic word of mouth.

\section{Sažetak}

Svrha - Istraživanjem se nastoji analizirati orijentacija na online kupovinu učenika srednjih škola kroz društvene medije i moderirajući učinak namjere pregledavanja društvenih medija na odnos između orijentacije na kupovinu i elektroničkog marketinga od usta do usta. Autori su konkretnije istražili učinak pretpostavljenih varijabli, što uključuje hedonističku i utilitarnu motivaciju, namjeru pregledavanja društvenih medija, marketing od usta do usta i namjeru kupovine.

Metodološki pristup - Podaci su prikupljeni na uzorku učenika viših razreda srednjih škola. Ukupni uzorak za testiranje istraživačkog modela obuhvatio je 191 učenika viših razreda srednje škole. Predložen je konceptualni model kako bi se prikazali odnosi između orijentacije na online kupovinu i namjere pregledavanja društvenih medija te kako marketing od usta do usta utječe na namjeru kupovine.

Rezultati i implikacije - Rezultati istraživanja pokazuju da specifični aspekti orijentacije ponašanja, $i$ to utilitarna i hedonistička motivacija, imaju značajan pozitivni utjecaj na poticanje namjera korisnika za pregledavanjem proizvoda na društvenim medijima. Namjera pregledavanja društvenih medija značajno je i pozitivno povezana s marketingom od usta do usta. Dodatno, pristup analize učinka medijatora pokazao je da namjera pregle- 
Limitations - One shortfall of the study was its narrow scope. The conceptual framework of the research was tested on senior high-school students. This limited sampling frame may affect the generalization of findings.

Originality - This paper provides valuable insights to marketers of the attitude of young online shoppers towards social media sites and their browsing activity. Moreover, a potential mediating process of browsing intention has received no attention to date. Addressing this, the current study tests a conceptual model that shows how shopping orientation ultimately leads to word of mouth through a mediating chain of social media browsing intention.

Keywords - social media, purchase intention, purchase decision davanja društvenih medija posreduje u odnosu između orijentacije na online kupovinu i elektroničkog marketinga od usta do usta.

Ograničenja - Jedan od nedostataka istraživanja jest što je obuhvaćen mali broj ispitanika. Konceptualni okvir istraživanja testiran je na učenicima viših razreda srednje škole. Ograničeni okvir uzorka može utjecati na generalizaciju nalaza.

Doprinos - Ovaj rad marketinškim stručnjacima daje vrijedan uvid u stav mladih online kupaca o društvenim medijima i aktivnostima njihova pregledavanja. Osim toga, potencijalni medijatorski (posrednički) proces namjere pregledavanja još nije privukao pozornost istraživača. Adresirajući tu činjenicu, ova studija testira konceptualni model koji pokazuje kako kupovna orijentacija u konačnici vodi prema marketingu od usta do usta kroz medijatorski učinak namjere pregledavanja društvenih medija.

Ključne riječi - društveni mediji, namjera kupovine, odluke o kupovini 


\section{INTRODUCTION}

The propensity to shop online is growing rapidly among customers across the world, and online sales support the Internet as a global marketing instrument. The presence of ubiquitous broadband Internet access and improved software tools has successfully enlarged the scalability of online business through social media. A massive e-business implementation nowadays has shifted the society's purchase and sale culture. It has moved from a market place concept that places a higher focus on the physical meeting between seller and buyer to a market space that relies more on virtual space to unite the necessities of both sides (Lee, Tsai \& Lanting, 2011). The world community recently admitted that the Internet is not only a medium to communicate. Moreover, it has a function as a transaction venue for consumers in a global market (Forsythe \& Shi, 2003; Baruah, 2012). The capability of Internet continuously evolves, so it is increasingly being recognized as a channel of information exchange and sale of goods or services among its users (Best, Foye, Taylor, Hazlett \& Manktelow, 2013). The beneficial properties of the Internet stimulate e-commerce marketers to pursue and attract buyers to their websites so as to sell a wide variety of goods and services worldwide (Gangeshwer, 2013). In the domain of social media, practitioners considering social media not only as a set of instruments that enable users to get involved in communication with fellow users (Paquette, 2013), but as an essential part of their shopping activity, can be an important component of social interaction among social media website and online communities (Goodman, Booth \& Matic, 2011). The myriad characteristics of online social media undeniably contributes to network density by shifting the scalability of influence, as well as the ways in which consumers share, evaluate, and select information (Moustakas, 2015).

Social media also delivers a new perspective to a whole new interactive platform on the Internet, generating the opportunity to interact with consumers, exchange commodities, and act as an ideal marketing medium, communication channel, and transactions driver (Oyza \& Edwin, 2016). Latest studies point out the potential of social media for product and brand marketing that enables organizations to be involved in a more effective and enlightening technique (Patino, Pitta \& Quinones, 2012). Despite the emergent usage of social media, which is indicative of a potentially new-fangled marketing and communication platform for marketers, little evidence exists of academic research which observes how Indonesian marketers can make use of social media as a virtual place for marketing and communication. In light of the above, this study will observe the impact of social media browsing based on shopping orientation and the impact on purchasing behavior in the youth market. This is so because they are typically more familiar with the Internet use and access to online shopping (Kim \& Ammeter, 2008). Additionally, Valentine, and Powers (2013) state that current students are regarded as the "net generation", as they are digitally empowered and strongly connected through the Internet for various purposes, including online shopping. Thus, this research was carried out to examine the influence of orientation towards online shopping done by young consumers using the information obtained through social media platforms; it will explore the potential of social media as an advertising channel, determine if shopping orientation has an impact on the purchasing behavior of consumers in the youth market, and establish the impact of shopping motivation - either utilitarian or hedonic - on purchase on social media in the target market. The framework of the study was tested in Indonesia due to limited literature on social media adoption among young consumers in the region. Different geographical and cultural settings may affect value creation in social and cultural context across nations (Adawiyah, 2015). The next goal was to detect the influence of search intention or product browsing to share the information on a desirable product (word of mouth) to a friend or acquaintance and, finally, the will to buy that product (purchase inten- 
tion). This paper also contributes to the literature by providing an analysis of the mediating effects of social media browsing intention on the relationship between shopping orientation and word of mouth.

\section{LITERATURE REVIEW AND HYPOTHESES DEVELOPMENT}

\subsection{Reasoned action theory and technological acceptance models}

Research conducted in order to analyze shopping behavior in the context of online shopping has been discussed in many studies and was based on two theories. Firstly, the Reasoned Action Theory by Fisbein and Ajzen (1975), in which they stated that behavior is conducted because an individual has interest or desire to do it (behavioral intention) or, in other words, behavioral intention will determine behavior. The second model, which is capable of being the basis for studying online shopping behavior, is Davis (1989) technological acceptance model. This theory that explains when an individual accepts computer technology, they will have a conviction as to its perceived usefulness. In this case, when an individual uses a new system, it will surely increase their work, and only perceived ease of use can assure the individual that the use of technology will need less effort. Therefore, the framework of this research utilizes both theories.

\subsection{Motivation of online purchasing (utilitarian and hedonism)}

An individual's characteristics, including their personality, will greatly influence the motivation or orientation in the decision-making process, without exception for online shopping (Rani, 2014). Furthermore, shopping is a sequential process, with motivation as the basis for an individual to buy something (Svatosová, 2013). Thus, motivation or orientation will push someone in deciding whether to shop or not. Holbrook and
Hirschman (1982) and Jackson, Stoel and Brantley (2011) stated that, from a higher level of abstraction, motivation can be considered as either a hedonic or a utilitarian value. Of the two, the utilitarian value referred in task-oriented, non-emotional outcome of shopping and more instilled in cognitive aspects of attitude (Kim, Martinez, McClure \& Kim, 2016). Therefore, someone with a utilitarian orientation will make the aim and rationality the reason to make a purchase decision (Kim \& Hwang, 2012; Anderson, Knight, Pookulangara \& Josiam, 2014). Meanwhile, persons with hedonic values are more focused on fulfilling the needs of multisensory, fantasy, or emotional elements, as they pertain to the experience-based aspects of consumption (Kaul, 2007). Several studies also stated some differences between both orientations. Individuals with a utilitarian orientation exhibit rational shopping behavior, driven mainly by functional motivations and evaluation of the functional benefit and effectiveness of time (Teo, 2001), while those with hedonic values mainly make an estimation of profit against experiential benefit and sacrifice (Overby \& Lee, 2006).

\subsection{Social media browsing intention}

Information search activity, which follows the stage of need acknowledgement, is an essential stage of a consumer's buying process (Satish \& Bharadhwaj, 2010), and the experience of shopping will be determined by the intensity of the searching process for any product since it is the result of a goal achievement process or exploration process done by an online shopper (Janiszewski, 1998). Online social media have been utilized for various activities, such as communicating, discussing, and also for online shopping. Kaplan and Haenlein (2011) found that social media also function as a means of personal and closed interaction with the consumer. Furthermore, social media's viral characteristics, mimicking a virus that spreads quickly, enable rapid sharing of the information on the offered product. Therefore, social media are a catalyst in doing marketing and e-commerce. 
The majority of Internet users' browsing activity in looking for information is based on two goals, i.e. pre-purchase and/or on-going information searches. However, Janiszewski (1998) states that the motivation for browsing is based on a goal or just exploration. The first behavior is more focused on the process of compiling information before purchasing any product, while the second one has no have specific goal in doing the browsing (Stone, 1954).

\subsection{Purchase intention}

The desire to buy or purchase intention, as referred to by Rahman, Saleem, Akhtar, Ali and Khan (2014), is defined as an individual's willingness to buy a product or utilize a service where, in the initial doing, an evaluation and consideration takes place before the purchasing process. Chen (2007) claimed that purchase intention is the character displayed by an online buyer when he/she wants to buy and is determined by his/her behavior, thus indicating the level of the buyer's desire to purchase. Additionally, according to Siti, Pan and Mohaini (2014), the intention to buy is a habit that occurs in the shopping market space for consumers when they purchase items.

\subsection{E-word of mouth in social media}

Word of mouth has evolved over time through changes in communication technology from a one-on-one relationship between two consumers without any intervention from marketers to a network co-production model, in which word of mouth is directly encouraged by marketers with the active co-production from online customer networks (Kozinets, De Valck, Wojnicki $\&$ Wilner, 2010). With the appearance of social media, electronic word of mouth (eWOM) has become a tool that represents a very pervasive and persuasive source of product information (Thoumrungroje, 2014).

Communication among social media users has an implication to the use of eWOM, which is a process of mouth-to-mouth communica- tion about a relevant and interesting service through a platform (Kimmel \& Kitchen, 2014). Furthermore, as eWOM is disseminated through a virtual context, information disperses at excessive speed and the evaluations are shared among netizen (King, Racherla \& Bush, 2014). The communication process that occurs consists in providing a recommendation, whether individually or in-group, which contains information about a product or service with the goal of giving the information personally. Mouth-tomouth communication through a virtual channel is among the communication media often used by companies since it is considered very effective in creating an influential marketing process, facilitating users to communicate with their existing networks, and is able to give profit to the company. Social media websites enable the diffusion of eWOM information among a massive quantity of people. Interpersonal repercussions resulting from eWOM are very big because, when people communicate and have interaction with one another, they influence each other and become reference for other people in buying a product (Berger, 2014).

\subsection{Correlation between shopping orientation and word of mouth}

Prior research showed hedonic and utilitarian orientations contribute significantly to other desirable outcomes for customers and retailers (Paridon, 2006). Considering the connection between hedonic and utilitarian values and wordof-mouth communication, people engage in sharing consumer-related information through eWOM for psychological reasons (Hennig-Thurau et al., 2010) and in relation to emotional responses to consumer attitude (Ravichandran, Deng \& Huang, 2015). These propositions are constructed, in part, on the concept that consumers talk to each other about something that provides social currency. Furthermore, when consumers interact effectively with a shopping environment, their acquisition of personal and social information experience during shopping online becomes the basis of one's proficiency in providing information. In turn, this information 
is implemented in the form of word-of-mouth communication (Paridon, 2005). According to Kakar (2013) and Jones, Reynolds, and Arnold (2006), the extent of utilitarian value that a consumer receives from utilitarian features is more associated with rationally-based cognitive processes, such as perceptions of value and equity evaluations in a product, this condition will help consumers with a utilitarian orientation achieve their functional benefit and practical goals; it will also encourage utilitarian consumers to engage in performance evaluation, recall, and interpretation of the event, improving communication and sharing important information with others. On the other hand, the extent of hedonic value received from hedonic features is connected with generating emotional arousal, which gives consumers pleasure, amusement, or fun. This process will heighten product involvement based on consumer experience, which in turn creates a post-purchase psychological tension or customer anxiety that $s$ relieved by sharing experiences with others. Hence, both motivations of shopping will directly and positively impact consumer eWOM. Lloyd, Yip and Luk (2011) and Kim, Sun and Kim (2013) claimed that wordof-mouth recommendation is closely related to the requirement for social acceptance of consumers, with regard to the necessity to communicate their consumption patterns, whether of utilitarian or hedonic orientation.

Ryu, Han and Jang (2010) also confirm that hedonic and utilitarian values among consumers influence positive behavioral intentions, such as repurchasing behavior in the future and saying positive things to others. Additional research conceptualized by Chang and Fang (2012) shows that hedonic and utilitarian values have significant influences on word of mouth. Similar to the aforementioned, Paridon (2005) confirmed that a positive utilitarian and hedonic experience contributes to one's willingness to engage in word-of-mouth communication.

H1: Utilitarian orientation positively influences word of mouth.
$\mathrm{H} 2$ : Hedonic orientation positively influences word of mouth.

\subsection{Correlation between utilitarian motivation and social media browsing intention}

The utilitarian orientation of social media browsing intention involves the external motivation of customers to use the Internet instrumentally as a source of problem solving. This kind of orientation is usually connected to speed, efficiency, and ease of problem solving through the help of net navigation. Furthermore, To, Liao and Lin (2007) believe that the utilitarian orientation is reflected in relation to browsing for information that leads to product purchase. Utilitarian-oriented customers are more motivated to look for information before making any purchase decision about a specific product. This task-related aspect of information search consists in comparing prices and products, consulting with friends, and final purchase. Utilitarian orientation also includes the effort to browse for product information that can effectively enhance the knowledge of the product a customer is most likely to purchase in the near future (Kim, Lee \& Kim, 2004). Utilitarian information search leads one to browse as many relevant sites as possible to optimize the utility of the purchase and to ensure that all relevant information is taken into consideration (Cotte, Chowdhury, Ratneshwar \& Ricci, 2006). When making an online buying decision, an online shopper with a utilitarian character will adjust his/her decision to the learning-oriented task at hand (Overby \& Lee, 2006). This will push the buyer to keep learning, making assessments and choices that are appropriate to the online products offered. The searching process of an individual of utilitarian orientation is displayed by their eagerness to look for various information on the product or service that is adjusted to their needs and also supported by the knowledge they have (Pöyry, Parvinen, Salo \& Blakaj, 2012). Therefore, the hypothesis that is set is the following:

H3: The desire to do product searching (social media browsing intention) will be positively influenced by utilitarian orientation. 


\subsection{Correlation between hedonic orientation and social media browsing intention}

A tendency to explore is the main influence for a person who has hedonic motivation in their browsing intention (Mikalef, Giannakos \& Pateli, 2013). Hedonic information search is claimed to lead a consumer to search content that satisfies him or her and that evokes positive emotions. Additionally, the hedonic shopping value of browsing is not determined by the objective to purchase, but by the consumer's more personal motives to participate in shopping by seeking experiences, entertainment and emotional satisfaction (Kazakeviciute \& Banyte, 2012). More specifically, hedonic information search is described as experiential information search. When customers with hedonic shopping value are engaged in browsing activity, their purpose is to achieve pleasure, happiness, fantasy, and enjoyment; they feel satisfied with the browsing itself as a form of sensory stimulation (Lee \& Andereck, 2011). Kim and Eastin (2011) revealed that hedonic shopping motivation is an important part and a strong predictor of experiential information seeking and impulse buying. To and others (2007) proposed that hedonic orientation will drive someone to do online site searching because it is appropriate to their behavior that puts ahead emotional experience. Hence, the hypothesis for this correlation is:

H4: The desire to do product searching (social media browsing intention) will be positively influenced by hedonic orientation.

\subsection{The mediating role of social media browsing intention}

In online shopping environments, consumers are motivated to browse and shop on the Internet for either utilitarian or hedonic motivation (Singh, 2014). Utilitarian-motivated shoppers will both browse and purchase items that they are looking for irrespective of the medium which they are presented with (To et al., 2007), thus supporting users with all necessary information about the product they are interested in, per- sonalized according to their requirements. Furthermore, consumers with hedonic preferences view shopping as a fun-filled activity and find it pleasurable (Oliver \& Raney, 2011). This orientation may assist people in escaping to an enjoyable situation (Arnolds \& Reynolds, 2012). As such, hedonic motivation plays a great role in encourage the process of browsing and social experiences (Overby \& Lee, 2006). As explained above, both utilitarian and hedonic motivations drive the information search (To et al., 2007). In these cases, utilitarian motive drives a consumer with goals in mind, as well as appealing to one's mind and logic, and encourages web browsing to search for price information, compare prices and possibly find the lowest price; this is followed by conducting an evaluation of the information received and an assessment of the quality of product attributes or product performance on selected attributes, and then building communication with other users. Meanwhile, hedonic motive driven web browsing places attention on the sensory attributes, generates emotional arousal (Koparal \& Çalık, 2015), and has a stronger focus on emotive opinions, multisensory, pleasure and excitement aspects of a product, as well as on aesthetic appreciation of a shopping experience (Çal \& Adams, 2014). Hence, when a shopping browsing journey is remarkably enjoyable, individuals with a hedonic preference are more encouraged to share their experiences with others and embolden friends and acquaintances to visit that online seller. Therefore, the eWOM process is initiated when a customer browses for products, which in turn may influence information acquisition and profound knowledge of a product (Vineyard, 2014), or just wants to share their joy and emotions about a successful browsing trip (Walsh, Gwinner \& Swanson, 2004). Therefore, it is crucial to consider browsing intention as a sequential procedure in relation to shopping motivation and eWOM, in which the browsing activity precedes eWOM.

Therefore, shopping orientation may not only have direct effects on eWOM, but also indirect effects mediated by browsing intention. Therefore, we propose that: 
H5: Social media browsing intention is a mediator between utilitarian motives and eWOM.

H6: Social media browsing intention is a mediator between hedonic motives and eWOM.

\subsection{Correlation between social media browsing intention and word of mouth}

The concept of browsing is associated with ongoing information acquisition which is found to be positively connected with the degree of knowledge concerning the product class and word-of-mouth activity (Rice, McCreadie \& Chang, 2001). When a consumer is engaged in browsing, they will conduct an evaluation and assessment of the quality or value-in-use from that product and then build communication with fellow users. The aspect that becomes very important is the sharing of information after browsing activity, known as post-browsing behavior (Mikalef et al., 2013), so that it will attract the attention of partners or friends that are in contact. Additionally, an e-shopper has a tendency to share information with peers on a product that they have seen before and would be of interest to friends (Ioanăs \& Stoica, 2014). In-depth knowledge of a product and consciousness of the latest trends also leads to relatively high levels of word-of-mouth activity.
This phenomenon has been explained by Venkatesh, Morris, Davis and Davis (2003) as a social influence formed by subjective norm (social pressure) that correlates a consumer's conviction and perception to other consumers. Therefore, the hypothesis that can be submitted is:

H7: Social media browsing intention will have a positive influence on word-of-mouth intention.

\subsection{Correlation between word- of-mouth and purchase intention}

The literature in marketing studies has proved the quality of word-of-mouth to be an important source in delivering information to consumers (Chevalier \& Mayzlin, 2006; Voyer \& Ranaweera, 2015). Online discussions in social media certainly have a significant effect on consumers' purchase intentions (Tsimonis \& Dimitriadis, 2014; Wang, Yu \& Wei, 2012). Brown, Broderick and Lee (2007) further note that word of mouth is the most effective method to get valuable and useful information in determining purchase intention. In addition, research done by Bansal and Voyer (2000) suggests that the capability of a person in delivering any information will very determine the influence of eWOM on the purchase intention of an online shopper. Therefore, the hypothesis for the previous statement is:

FIGURE 1: Conceptual research design

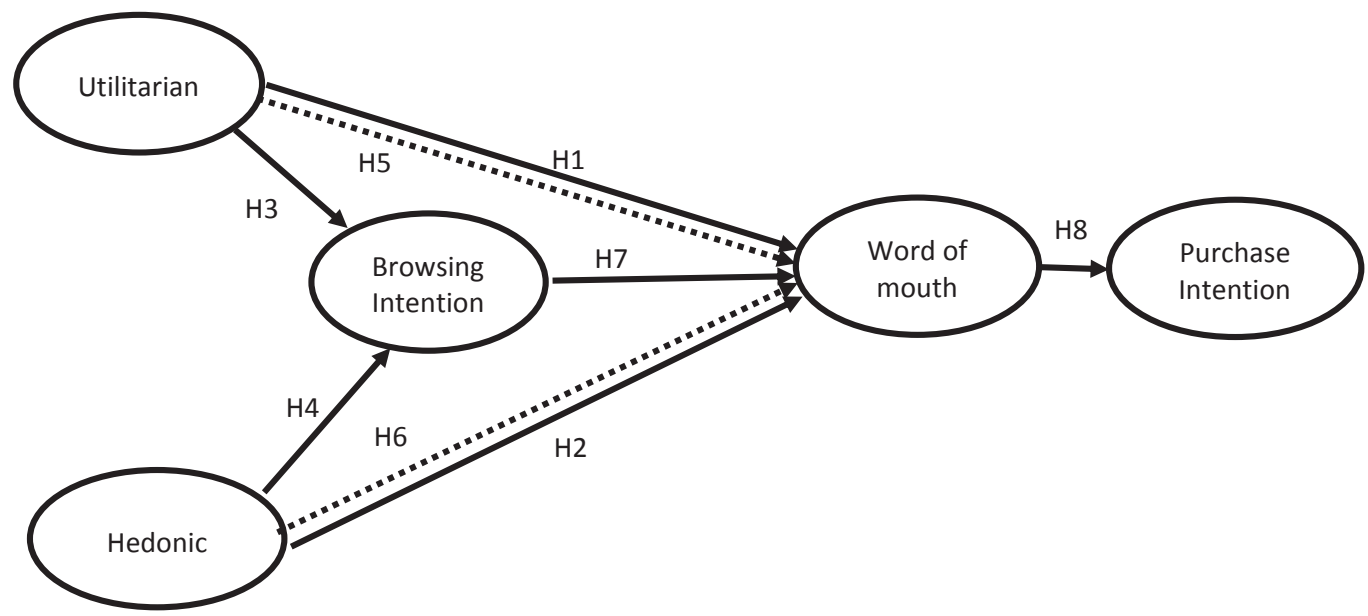


H8: Word of mouth will positively influence purchase intention.

Based on the developed hypotheses that were formed by the relationships among previous constructs, the researcher provided a research model illustrated on the figure 1.

\section{METHODOLOGY}

\subsection{Assessment and instrumentation}

This research uses quantitative approach that has causal characteristics since it will examine the influence of variables to be analyzed. The collection of data was conducted directly using a self-administered survey. The research was divided into two parts: first, it looked into the descriptive profile of the respondents, usage intensity, and duration of the use for each day. Secondly, a multi-item scale taken from previous research studies was used.

\subsection{Instrument development}

The construct was assessed using 5 question items in the form of the five-point Likert scale, in which 1 indicates strong disagreement and 5 strong agreement. The questions used in this research are similar to those developed by previous research, such as that of To and others (2007), Wolfinbarger and Gilly (2001), and Westbrook and Black (1985) with several adjustments for the local context.

\subsection{Control variables}

In keeping with previous studies, gender, age, and experience of respondents have been treated as control variables for all statistical analyses, as these variables have the potential to confound the results.

\subsection{Sample and data collection}

The data collection in this research used purposive sampling with the criterion of consumers who had conducted online shopping at least twice. The characteristics of the sample are: male and female adolescents in the age range of 17-19 year olds, who have actively kept in touch with online shopping through social media at least for the last one-year period. This research focuses on fashion clothing (e.g. apparel, footwear, and fashion accessories) because it is closely related to daily life, having essential and highly psychological functions in young consumers' lives. The data was collected through a self-administered survey.

The survey that was completed by 191 respondents was carried out from January $1^{\text {st }}$ to February $15^{\text {th }} 2016$. The optimal quantity of the sample in this research refers to a suggestion in Hair, Black, Babin and Anderson (2010), which is 5 to 10 times the number of indicators used for the whole latent variable. There are 18 indicators in this research, thus the minimum respondent number is $18 \times 5=$ 90 respondents, while the maximum number is 18 $\times 10=180$ respondents, so the sample size in this research is enough to fulfill the requirement.

\subsection{Characteristics of respondents}

The result of descriptive analysis of the respondents indicates that female student population dominated the Internet use for the purposes of online shopping, with a total of 118 students or $61.8 \%$, while the number of male students totaled 78 or $38.2 \%$. In terms of the Internet access, 130 students or $68.1 \%$ spends under an hour, while 59 or $30.9 \%$ spends between 1 to 5 hours, and 2 students or $1 \%$ spends over five hours using the Internet. As to the cost allocation to access the Internet, less than Rp. 100.000 per month has been spent by 181 respondents or $94.8 \%$, while more than 10 respondents have spent between Rp. 100.000 and 300.000. Additionally, fashion purchases of apparel, footwear, and fashion accessories were statistically dominated by female students at $64.8 \%$ of the total, with male student accounting for only $36.2 \%$. Based on the results of descriptive analysis, it can be said that a great number of students accessing the Internet is female; this is done specifically in time and with a cost allocation sufficient to prove that students are adequately

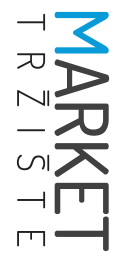


active in accessing the Internet and carrying out activities in social media.

\section{ANALYSIS AND RESULTS}

The research data were analyzed at individual level by SPSS, AMOS 20 version. A confirmatory factor analysis was employed to confirm the fit of all the measurements. The CFA identified a correlation between observed variables and their respective latent factors. The SEM offers a solution to the two-step verification method in which both the measurement model and the structural model are confirmed (Anderson \& Gerbing, 1988).

\subsection{Measurement model}

In the first step, to assess the measurement model, reliability and validity analyses were conducted. Table 1 presents the result of all factor loadings on the corresponding latent constructs, achieving the required value and greater than the recommended 0.7 (Nunnally \& Bernstein, 1994). Therefore, all indicators in this study were valid and of acceptable internal consistency. The following measurement is average variance extracted, the AVE representing a confirmatory test of variance captured by a construct in relation to the variance due to random measurement er- ror. The AVE of each measure in this study was set at 0.5 (Fornell \& Larcker, 1981; Hatcher, 1994) or extracted more than or equal to $50 \%$ of the variance, as the cut-off value (Bagozzi \& Yi, 1988). The overall AVE values were calculated and they were all greater than the recommended value of 0.5 , suggesting that the variance explicated by each construct exceeds that due to measurement error (Fornell \& Larcker, 1981). The reliability of the factor is measured by using composite reliability. Composite reliability for all factors in our measurement model was calculated at above required 0.5 levels (Fornell \& Larcker, 1981). In our research, discriminant validity of the measures was examined by comparing the square root of the AVE to each variable relation (Fornell \& Larcker, 1981). This revealed discriminant validity to be established between two constructs' correlation among indicators and greater than the squared correlation among construct (Hair et al., 2010) (see Table 2).

The overall fit of the measurement model was evaluated based on 10 indices associated with cut-off values suggested by Bagozzi, Yi and Phillips (1991), which indicated a good fit (x2/df $=84.760$, degrees of freedom $(\mathrm{df})=80, \mathrm{GFI}=$ 0.947, AGFI $=0.920, \mathrm{NNFI}=0.995, \mathrm{NFI}=0.942, \mathrm{CFI}$ $=0.996)$, while RMSEA $=0.018$, SRMR $=0.0354$, and $R M R=0.028$, exceeded the cut-off values.

TABLE 1: Measurement model

\begin{tabular}{|c|c|c|c|c|c|c|c|}
\hline Construct & Item & Mean & SD & $\begin{array}{l}\text { Factor } \\
\text { Loading }\end{array}$ & CR & AVE & Cronbach a \\
\hline \multirow{3}{*}{ Utilitarian } & $\mathrm{X} 1$ & 3.61 & 0.932 & 0.807 & \multirow{3}{*}{0.832} & \multirow{3}{*}{0.623} & \multirow{3}{*}{0.829} \\
\hline & $\times 2$ & 3.59 & 0.900 & 0.769 & & & \\
\hline & X3 & 3.43 & 1.083 & 0.792 & & & \\
\hline \multirow{3}{*}{ Hedonic } & $\mathrm{X} 1$ & 3.93 & 0.862 & 0.784 & \multirow{3}{*}{0.869} & \multirow{3}{*}{0.688} & \multirow{3}{*}{0.868} \\
\hline & $\times 2$ & 3.88 & 0.838 & 0.825 & & & \\
\hline & X3 & 3.93 & 0.833 & 0.877 & & & \\
\hline \multirow{3}{*}{$\begin{array}{l}\text { Social media } \\
\text { browsing } \\
\text { intention }\end{array}$} & $\mathrm{X} 1$ & 3.90 & 0.849 & 0.855 & \multirow{3}{*}{0.865} & \multirow{3}{*}{0.682} & \multirow{3}{*}{0.866} \\
\hline & $\times 2$ & 3.93 & 0.864 & 0.812 & & & \\
\hline & $\times 3$ & 3.78 & 0.829 & 0.809 & & & \\
\hline \multirow{3}{*}{$\begin{array}{l}\text { Electronic word- } \\
\text { of-mouth }\end{array}$} & $\mathrm{X} 1$ & 3.82 & 0.900 & 0.833 & \multirow{3}{*}{0.864} & \multirow{3}{*}{0.679} & \multirow{3}{*}{0.863} \\
\hline & $X 2$ & 3.81 & 0.884 & 0.848 & & & \\
\hline & X3 & 3.75 & 0.910 & 0.790 & & & \\
\hline \multirow{3}{*}{$\begin{array}{l}\text { Purchase } \\
\text { Intention }\end{array}$} & $\mathrm{X} 1$ & 3.691 & 0.884 & 0.759 & \multirow{3}{*}{0.821} & \multirow{3}{*}{0.605} & \multirow{3}{*}{0.819} \\
\hline & $\times 2$ & 3.659 & 0.942 & 0.837 & & & \\
\hline & $\times 3$ & 3.680 & 0.898 & 0.733 & & & \\
\hline
\end{tabular}


TABLE 2: Discriminant Validity

\begin{tabular}{|l|c|c|c|c|c|c|c|}
\hline Variable & Mean & SD & $\mathbf{1}$ & $\mathbf{2}$ & $\mathbf{3}$ & $\mathbf{4}$ & $\mathbf{5}$ \\
\hline Utilitarian & 3.548 & 0.976 & $\mathbf{0 . 7 8 9}$ & & & & \\
\hline Hedonic & 3.918 & 0.976 & -0.059 & $\mathbf{0 . 8 3 0}$ & & & \\
\hline Social media browsing & 3.870 & 0.849 & 0.312 & 0.494 & $\mathbf{0 . 8 2 6}$ & & \\
\hline Word-of-mouth & 3.797 & 0.897 & 0.309 & 0.328 & 0.445 & $\mathbf{0 . 8 2 4}$ & \\
\hline Purchase intention & 3.677 & 0.907 & 0.005 & 0.312 & 0.371 & 0.246 & $\mathbf{0 . 7 7 8}$ \\
\hline
\end{tabular}

Note: Square-root of AVE on the diagonal on bold; Correlations off-diagonal

\subsection{Structural model}

The data were tested by using the AMOS maximum likelihood estimation technique. The SEM results show that GFI (0.925), AGFI (0.900), NFI (0.902), NNFI (0.983), and CFI (0.986) all exceeded the cutoff values, while $\times 2 / d f(147.445)$, RMR (0.050), SRMR (0.0705), and RMSEA (0.028) met the recommended threshold criteria. Confirmatory Factor Analysis is used to determine how well the model fits to the data (Suhr, 2006). In sum, the fit indices were found to be satisfactory and in accordance with research framework. Figure 3 illustrates the main path coefficients, t-values, and standard of error.

TABLE 3: Effect of shopping orientation on eWOM

\begin{tabular}{|l|c|c|c|}
\hline Path & Path Coefficient & SE & t-Value \\
\hline Direct Effect Model & & & \\
\hline H1: Utilitarian - eWOM & 0.329 & 0.071 & $4.004^{* * *}$ \\
\hline H2: Hedonic - eWOM & 0.362 & 0.096 & $4.352^{* * *}$ \\
\hline & & & \\
\hline Control Variable & & & \\
\hline Age & -0.028 & 0.085 & -0.393 \\
\hline Gender & -0.043 & 0.111 & -0.596 \\
\hline EXP & 0.02 & 0.07 & 0.278 \\
\hline
\end{tabular}

TABLE 4: Mediating effect of social media browsing intention

\begin{tabular}{|l|c|c|c|}
\hline Path & Path Coefficient & SE & t-Value \\
\hline Mediation Model & & & \\
\hline H1: Utilitarian - eWOM & 0.228 & 0.075 & $2.661^{* *}$ \\
\hline H2: Hedonic - eWOM & 0.212 & 0.111 & $2.214^{* *}$ \\
\hline H3: Utilitarian - SMBI & 0.342 & 0.063 & $4.432^{* * *}$ \\
\hline H4: Hedonic-SMBI & 0.516 & 0.089 & $6.318^{* * *}$ \\
\hline H7: SMBI - eWOM & 0.290 & 0.107 & $2.713^{* *}$ \\
\hline H8: eWOM-PI & 0.267 & 0.077 & $3.051^{* *}$ \\
\hline & & & \\
\hline Control Variable & & & \\
\hline Age & -0.053 & 0.083 & -0.76 \\
\hline Gender & -0.058 & 0.108 & -0.831 \\
\hline EXP & 0.038 & 0.068 & 0.549 \\
\hline
\end{tabular}

Notes: Significance on the t-values (one-tailed) ${ }^{* *} p<0.05 ;{ }^{* *} p<0.01$ 


\subsection{Hypotheses testing}

The eight hypotheses examined in this research were analyzed using the structural equation model (SEM) to simultaneously examine the influence of each independent variable on a dependent variable. The testing of hypotheses was performed based on the result of model processing that has been executed previously. From the data processing result, coefficient quantity of each variable or path coefficient can be known. Squared multiple correlation was used as an evaluation model to analyze the dependent variables in SEM, whereas the independent variables used standardized regression.

The results of the structural equation modeling indicated that the direct effect model between utilitarian orientation with eWOM showed a significant correlation between the two variables $(B=0.329, t=4.004, p<0.001)$ and accounted for a significant amount of variance in eWOM $(R 2=0.507)$. Therefore, the first hypothesis is accepted while the effect of the control variables which consist of education, gender, age, and experience proved to be insignificant. Next hypotheses, as shown in Table 3, hedonic orientation is positively associated with eWOM ( $\beta$ : 0.362 , $t=4.352, p<0.001$ ), supporting $\mathrm{H} 2$.

Furthermore, H3 stated that utilitarian orientation is associated with social media browsing intention. As shown in the mediating effect model, utilitarian orientation is related with SMBI $(\beta$ $=0.342$, $t=4.432 ; p<0.001)$, supporting H3. Hedonic orientation was found to be significantly related to $\mathrm{SMBI}(\beta=0.516 ; \mathrm{t}=6.318 ; \mathrm{p}<0.05)$, supporting $\mathrm{H} 4$.

Research hypotheses suggest that social media browsing intention mediates the relationship between the two variables and the dependent variable. Thus, this study has inspected the mediating role of social media browsing intention. We used a three-step approach suggested by Baron and Kenny (1986) to test the mediating impact of SMBI on the relation be- tween shopping orientations on eWOM. First, as suggested by Baron and Kenny (1986), for mediation to be established, the exogenous variables should significantly impact the dependent variable. Second, the proposed mediating variables should relate to the assigned outcome variables. As can be seen in Table 3, these two criteria are achieved. Third, according to the recommendation by Baron and Kenny's (1986), the impact of the independent on the dependent variable should be zero (full mediation) or reduced (partial mediation) when the mediating variable is entered. The results in Table 3 and 4 (comparing the direct effect model and the mediation model) show that the presence of social media browsing intention diminishes the influence of utilitarian and hedonic orientation on eWOM. As presented in Table 3, utilitarian orientation ( $\beta=0.329$, $t=4.004, p<0.001$, direct effect model) and hedonic orientation ( $\beta$ : 0.362, $t=4.352, p<0.001$, direct effect model) showed a significant positive association with eWOM. Hence, condition 1 for mediation was supported, the results of the mediating model provide support for Condition 2 since utilitarian orientation $(\beta=0.342, t=4.432, p<0.001$ ) and hedonic orientation $(\beta=0.516$; $t=6.318$; $p<0.05)$ showed a significant positive correlation with social media browsing intention and $\mathrm{SMBl}$ is related to the eWOM $(B=0.277, \mathrm{t}=2.713$, $\mathrm{p}<0.001)$. Meanwhile, Condition 3 was also supported by the result shown in Table 4 , since the relationship between utilitarian orientation ( $\beta=$ 0.228; $\mathrm{t}=2.661, \mathrm{p}<0.05)$ and hedonic orientation $(\beta=0.212 ; t=2.214, p<0.05)$ on eWOM becomes diminished when SMBI is entered into the model. Thus, hypotheses $\mathrm{H} 5$ and $\mathrm{H} 6$ were partially supported.

Additionally, as presented in Table 4, SMBI showed a significant positive correlation with eWOM ( $\beta=0.290, t=2,713, p<0.001$ ), supporting H7. Finally, eWOM positively impacts purchase intention ( $B=0.267, t=3.051, p<0.001$ ), supporting $\mathrm{H} 8$. 


\section{RESEARCH DISCUSSION AND IMPLICATION}

\subsection{Discussion}

The first and second hypotheses of this study provide support that both utilitarian and hedonic orientation are positively associated with supported E-WOM of users. Theory proposed that word-of-mouth is a form of interpersonal interaction (Nasiruddin \& Hashim, 2015) and emotional responses to consumption experience or situations (Martensen \& Mouritsen, 2014) that significantly form consumer decisions. Hence, when online consumers effectively interrelate with suitable shopping environment, their procurement of individual and collective information is grounded in their hedonic emotional experiences and their utilitarian final outcomes. Sequentially, this information will be implemented in the form of word-of-mouth communication that delivered to their friends and acquaintances (Paridon, Carraher \& Carraher, 2006). Jantarat and Shannon (2016) argued that consumers who achieve a satisfactory functional or substantial emotional outcome from shopping generally show a greater likelihood of favorable word of mouth.

The influence of utilitarian motivation of online shoppers on social media browsing intention indicates that the orientation provides psychological encouragement to learn through social media. This is so because a person of utilitarian orientation takes knowledge as a measuring point in searching the desired product through social media. This result is in line with the research done by Cotte and others (2006), which explains that utilitarian motivation has a strong correlation with searching behavior. The same result has been suggested by Ramlugun and Jugurnauth (2014) in their research, which found that the convenience factor and cost saving becomes the main predictor for someone of utilitarian orientation in browsing a product through social media.

The research result indicating a positive correlation between hedonic motivation and social media browsing intention shows that, in purchasing, an online shopper of hedonic motivation depends on the emotional needs which are mainly for pleasure (Bhatnagar \& Ghose, 2004). Some researchers have proved that individuals of hedonic orientation feel pleasure and are delighted because of their shopping experience (Kim \& Hwang, 2012), and that they enjoy the process of obtaining information about a service or product they want (Mathwick \& Rigdon, 2004). Therefore, the use of various social media as sensory stimulation is a way for individuals of hedonic motivation to satisfy their desire.

The influence of social media browsing intention on electronic word of mouth is accepted in this research. This finding indicates that word of mouth or communication about a product and a service is affected by the desirability of browsing, as supported by the research done by Mikalef and others (2013) and Shen, Li and DeMoss (2012) which stated that social media or communication means makes it easier for every user to share any information which impacts the spread of product information. Additionally, Sandes and Urdan (2013) in their research found that browsing through social media makes it possible for information to reach a wider distribution and spread since it is delivered through a media that is massive and comprehensive.

The eighth hypothesis, stating that word of mouth has influence on purchase intention, is statistically significant. This is so because the opinion or mindset built by an individual about certain products or services is informal and can influence the decision of another individual in making a purchase (Mikalef et al., 2013). Additionally, Reza Jalilvand and Samiei (2012) stated that word of mouth is regarded as an important source when a consumer decides to buy. The result of research by Vázquez-Casielles, Suárez-Álvarez and del Río-Lanza (2013) also indicated that eWOM can be either positive or negative. Positive eWOM encourages purchase, whereas negative eWOM discourages purchase. In line with the aforementioned literature on eWOM, Ennew, Banerjee and Li (2000) also showed

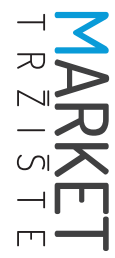




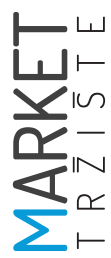

that word of mouth has negative and positive content as a result of communication, which interlaces in a group, community or cluster that can eventually change someone's opinion on a particular product or service they want to buy.

In this context, the hypothesis concerning the mediating role of browsing between shopping orientation and eWOM was also supported. In other words, both utilitarian and hedonic motives influence browsing, which in turn influences eWOM. Theoretical arguments concerning browsing intention rely on communication built between consumers and how they gather and exchange information about products, and on how they consume and use this information. Due to the increasing new media platform, consumers have the opportunity to actively provide and seek information about new products or services. Furthermore, after post-browsing activity, it enables the audience to talk about and share information about products and services (Hennig-Thurau et al., 2010). In addition, Jansen, Zhang, Sobel and Chowdury (2009) found that, based on their motivation, individuals use social media to find general information, to ask questions, to take part in other information-seeking and sharing activities about products and services, and continue spreading around their experiences.

\subsection{Implication}

In previous studies, the impact of shopping orientation and various virtual shopping behaviors was central to research; however, to date, the literature has not addressed social media browsing intention as a mediating variable. Therefore, the present study contributes to the research on shopping orientation by offering insights into the factors that contribute to the utilization of social media browsing intention in consumer word of mouth and purchase intention. However, the major contribution of this study is in developing a comprehensive conceptual model which examines the determinants of shopping orientation, social media browsing intention on electronic work of mouth, and finally influencing consumers' purchase intention. Our research model also confirmed the mediating role of social media browsing intention in the context of online shopping, which showed the explanatory power on electronic word of mouth. This finding is important because it suggests that, when online shoppers browse through social media, this online information search will positively influence consumer attitudes and subsequently promote information sharing with peers while also influencing their purchase intentions. Consequently, online retailers should satisfy the hedonic and utilitarian motives of online customers by engaging them in more browsing activity in information search, word-of-mouth endorsement, and online purchase. Utilitarian characteristics are an important aspect to be considered for online shopping through social media. Hence, marketers should take into consideration the convenience of using social media and the selection of products existing on such social media websites, since these elements are found to be the most important contributors in explaining why consumers browse products, to enable immediate content sharing with peers.

From the hedonic orientation used in the present study, marketers should design such social media websites that will satiate the entertainment and enjoyment goals of young consumers. These social media sites should be pleasing and incorporate entertaining multi-sensory stimuli, fantasy and emotive aspects, enjoyment, and emotional immersion, so that the customers are encouraged to browse and spend extra time at the website (Nah, Eschenbrenner \& DeWester, 2011). Finally, it stands to reason that social media browsing intention will be facilitated by a greater fascination of adolescent e-shoppers, who are keen on finding out the latest trends and sharing that information with friends and acquaintances.

\section{LIMITATION}

The results of this study should be considered with the following limitations. This research has been conducted with senior high-school stu- 
dents. Although this age group constitutes the majority of social media users, they may not precisely reflect the whole population. Therefore, the findings cannot be generalized in terms of the demographics or population in general. Furthermore, since data from the sample was collected in Indonesia, generalizability to other countries might be limited due to cultural differences in shopping behavior orientation. Finally, since this study only considered social media as a channel for online shopping, it is unclear whether the findings of the statistical model can be generalized with regard to other online marketplaces.

\section{SCOPE OF FUTURE RESEARCH}

For further research, we recommend the use of different methodologies such as longitudinal research, and a larger sample of respondents from different socio-economic backgrounds based on the type of school they attend (either public or private school) who might display diverse behavioral patterns to make the results more representative. Moreover, conducting a more widespread selection of schools to participate in the research would also be worthwhile to help verify the result of the study and possibly indicate further dissimilarities among the personality characteristics of students.

\section{References}

1. Adawiyah, W. R. (2015). Impression management tactics, work related behavior and perceived individual performance of sales clerks: a case of Indonesia. International Journal of Applied Business and Economic Research, 13(7), 5481-5501.

2. Anderson, K. C., Knight, D. K., Pookulangara, S., \& Josiam, B. (2014). Influence of hedonic and utilitarian motivations on retailer loyalty and purchase intention: a Facebook perspective. Journal of Retailing and Consumer Services, 21(5), 773-779.

3. Anderson, J. C., \& Gerbing, D. W. (1988). Structural equation modeling in practice: A review and recommended two-step approach. Psychological bulletin, 103(3), 411-423.

4. Arnold, M. J., \& Reynolds, K. E. (2012). Approach and avoidance motivation: investigating hedonic consumption in a retail setting. Journal of Retailing, 88(3), 399-411.

5. Bagozzi, R. P., \& Yi, Y. (1988). On the evaluation of structural equation models. Journal of the academy of marketing science, 16(1), 74-94.

6. Bagozzi, R. P., Yi, Y., \& Phillips, L. W. (1991). Assessing construct validity in organizational research. Administrative science quarterly, 36, 421-458.

7. Bansal, H. S., \& Voyer, P. A. (2000). Word-of-mouth processes within a services purchase decision context. Journal of service research, 3(2), 166-177.

8. Baron, R. M., \& Kenny, D. A. (1986). The moderator-mediator variable distinction in social psychological research: Conceptual, strategic, and statistical considerations. Journal of personality and social psychology, 51(6), 1173-1182.

9. Baruah, T. D. (2012). Effectiveness of social media as a tool of communication and its potential for technology enabled connections: A micro-level study. International Journal of Scientific and Research Publications, 2(5), 1-10.

10. Berger, J. (2014). Word of mouth and interpersonal communication: A review and directions for future research. Journal of Consumer Psychology, 24(4), 586-607.

11. Best, P., Foye, U., Taylor, B., Hazlett, D., \& Manktelow, R. (2013). Online interactive suicide support services: quality and accessibility. Mental Health Review Journal, 18(4), 226-239.

12. Bhatnagar, A., \& Ghose, S. (2004). A latent class segmentation analysis of e-shoppers. Journal of Business Research, 57(7), 758-767. 
13. Brown, J., Broderick, A. J., \& Lee, N. (2007). Word of mouth communication within online communities: Conceptualizing the online social network. Journal of interactive marketing, 21(3), 2-20.

14. Çal, B., \& Adams, R. (2014). The Effect of Hedonistic and Utilitarian Consumer Behavior on Brand Equity: Turkey-UK Comparison on Coca Cola. Procedia-Social and Behavioral Sciences, 150, 475-484.

15. Chang, H-H., \& Fang, W. (2012). The effects of shopping value on retail outcomes: a comparison between department stores and hypermarkets. The Service Industries Journal, 32(14), 2249-2263.

16. Chen, M-F. (2007). Consumer attitudes and purchase intentions in relation to organic foods in Taiwan: Moderating effects of food-related personality traits. Food Quality and Preference, 18(7), 1008-1021.

17. Chevalier, J. A., \& Mayzlin, D. (2006). The effect of word of mouth on sales: Online book reviews. Journal of marketing research, 43(3), 345-354.

18. Cotte, J., Chowdhury, T. G., Ratneshwar, S., \& Ricci, L. M. (2006). Pleasure or utility? Time planning style and Web usage behaviors. Journal of interactive marketing, 20(1), 45-57.

19. Davis, F. D. (1989). Perceived Usefulness, Perceived Ease of Use, and User Acceptance of Information Technology. MIS Quarterly, 13(3), 319-340.

20. Ennew, C. T., Banerjee, A. K., \& Li, D. (2000). Managing word of mouth communication: empirical evidence from India. International Journal of Bank Marketing, 18(2), 75-83.

21. Fisbein, M., \& Ajzen, I. (1975). Belief, attitude, intention and behavior: an introduction to theory and research. Boston, MA: Addison-Wiley Publishing Company.

22. Fornell, C., \& Larcker, D. F. (1981). Evaluating structural equation models with unobservable variables and measurement error. Journal of marketing research, 18(1), 39-50.

23. Forsythe, S. M., \& Shi, B. (2003). Consumer patronage and risk perceptions in Internet shopping. Journal of Business Research, 56(11), 867-875.

24. Gangeshwer, D. K. (2013). E-commerce or Internet Marketing: A business Review from Indian context. International Journal of u-and e-Service, Science and Technology, 6(6), 187-194.

25. Goodman, M. B., Booth, N., \& Matic, J. A. (2011). Mapping and leveraging influencers in social media to shape corporate brand perceptions. Corporate Communications: An International Journal, 16(3), 184-191.

26. Hair, J. F., Black, W. C., Babin, B. J., \& Anderson, R. E. (2010). Multivariate data analysis: A global perspective. Upper Saddle River, NJ: Pearson Prentice Hall.

27. Hatcher, L. (1994). A step-by-step approach to using the SAS(R) system for factor analysis equation modeling. Cary, NC: SAS Institute.

28. Hennig-Thurau, T., Malthouse, E. C., Friege, C., Gensler, S., Lobschat, L., Rangaswamy, A., \& Skiera, B. (2010). The Impact of New Media on Customer Relation. Journal of Service Research, 13, 311-330.

29. Holbrook, M. B., \& Hirschman, E. C. (1982). The experiential aspects of consumption: Consumer fantasies, feelings, and fun. Journal of consumer research, 9(2), 132-140.

30. Ioanăs, E., \& Stoica, I. (2014). Social media and its impact on consumers' behavior. International Journal of Economic Practices and Theories, 4(2), 295-303.

31. Jackson, V., Stoel, L., \& Brantley, A. (2011). Mall attributes and shopping value: differences by gender and generational cohort. Journal of retailing and consumer services, 18(1), 1-9.

32. Janiszewski, C. (1998). The influence of display characteristics on visual exploratory search behavior. Journal of consumer research, 25(3), 290-301.

33. Jansen, B. J., Zhang, M., Sobel, K., \& Chowdury, A. (2009). Micro-blogging as online word of mouth branding. In: CHI'09 Extended Abstracts on Human Factors in Computing Systems (pp. 3859-3864). ACM.

34. Jantarat, J., \& Shannon, R. (2016). The moderating effects of in-store marketing on the relationships between shopping motivations and loyalty intentions. The International Review of Retail, Distribution and Consumer Research, 26(5), 566-588. 
35. Jones, M. A., Reynolds, K. E., \& Arnold, M. J. (2006). Hedonic and utilitarian shopping value: Investigating differential effects on retail outcomes. Journal of Business Research, 59(9), 974-981.

36. Kakar, A. K. (2013). Exploring the impact of hedonic and utilitarian value of information systems on user loyalty and word-of-mouth. Utilitarian-Hedonic Impacts of Information Systems, 75-81.

37. Kaplan, A. M., \& Haenlein, M. (2011). Two hearts in three-quarter time: How to waltz the social media/viral marketing dance. Business Horizons, 54(3), 253-263.

38. Kaul, S. (2007). Hedonism and culture: impact on shopping behaviour a research agenda. Vikalpa, 32(3), 81-89.

39. Kazakeviciute, A., \& Banyte, J. (2012). The Relationship of Consumers 'Perceived Hedonic Value and Behavior. Engineering Economics, 23(5), 532-540.

40. Kim, D. J., \& Hwang, Y. (2012). A study of mobile Internet user's service quality perceptions from a user's utilitarian and hedonic value tendency perspectives. Information Systems Frontiers, 14(2), 409-421.

41. Kim, D., \& Ammeter, A. P. (2008). Examining shifts in online purchasing behavior: Decoding the 'net generation'. Proceedings of Allied Academies International Conference. Academy of Information and Management Sciences.

42. Kim, J., Lee, H., \& Kim, H. (2004). Factors affecting online search intention and online purchase intention. Seoul Journal of Business, 10(2), 27-48.

43. Kim, S., \& Eastin, M. S. (2011). Hedonic tendencies and the online consumer: an investigation of the online shopping process. Journal of Internet Commerce, 10(1), 68-90.

44. Kim, S., Martinez, B., McClure, C. S., \& Kim, S. H. (2016). E-WOM Intentions towards Social Media Messages. Atlantic Marketing Journal, 5(1), 137-154.

45. Kim, S-B., Sun, K.-A., \& Kim, D.-Y. (2013). The influence of consumer value-based factors on attitude-behavioral intention in social commerce: The differences between high-and low-technology experience groups. Journal of Travel \& Tourism Marketing, 30(1/2), 108-125.

46. Kimmel, A. J., \& Kitchen, P. J. (2014). Word of mouth and social media. Journal of Marketing Communications, 20(1/2), 2-4.

47. King, R. A., Racherla, P., \& Bush, V. (2014). What we know and don't know about online wordofmouth: a review and synthesis of literature. Journal of Interactive Marketing, 28(3), 167-183.

48. Koparal, C., \& Çalık, N. (2015). Hedonic Consumption Characteristics Related to Products and Services where Fashion Involvement Plays an Important Role, A Field Study from Eskisehir, Turkey. International Journal of Social Sciences, 4(1), 13-37.

49. Kozinets, R. V., De Valck, K., Wojnicki, A. C., \& Wilner, S. J. (2010). Networked narratives: Understanding word-of-mouth marketing in online communities. Journal of marketing, 74(2), 71-89.

50. Lee, K.-W., Tsai, M.-T., \& Lanting, M. C. L. (2011). From marketplace to marketspace: Investigating the consumer switch to online banking. Electronic Commerce Research and Applications, 10(1), 115125.

51. Lee, W. J., \& Andereck, K. (2011). The Effect of the Fulfillment of Hedonic and Aesthetic Information Needs of a Travel Magazine on Tourist Decision Making. Proceedings of International TTRA Conference, June 19-21, 2011, London.

52. Lloyd, A. E., Yip, L. S., \& Luk, S. T. (2011). An examination of the differences in retail service evaluation between domestic and tourist shoppers in Hong Kong. Tourism Management, 32(3), 520 533.

53. Martensen, A., \& Mouritsen, J. (2014). How ad-talk and word-of-mouth influence consumers' responses. Innovative marketing, 10(2), 58-69.

54. Mathwick, C., \& Rigdon, E. (2004). Play, flow, and the online search experience. Journal of Consumer Research, 31(2), 324-332. 
55. Mikalef, P., Giannakos, M., \& Pateli, A. (2013). Shopping and word-of-mouth intentions on social media. Journal of theoretical and applied electronic commerce research, 8(1), 17-34.

56. Moustakas, E. (2015). The impact of Social Networking on consumer behaviour. ERPBSS conference. November 2015.

57. Nah, F. F. H., Eschenbrenner, B., \& DeWester, D. (2011). Enhancing brand equity through flow and telepresence : A comparison of 2D and 3D virtual worlds. MIS Quarterly, 35(3), 731-747.

58. Nasiruddin, K. B., \& Hashim, H. B. (2015). Electronic word of mouth: exploring consumer reaction and purchase intention. Journal of Global Business and Social Entrepreneurship, 1(1), 85-93.

59. Nunnally, J. C., \& Bernstein, I. H. (1994). Psychometric Theory. New York, NY: McGraw-Hall.

60. Oliver, M. B., \& Raney, A. A. (2011). Entertainment as pleasurable and meaningful: Identifying hedonic and eudaimonic motivations for entertainment consumption. Journal of Communication, 61(5), 984-1004.

61. Overby, J. W., \& Lee, E-J. (2006). The effects of utilitarian and hedonic online shopping value on consumer preference and intentions. Journal of Business Research, 59(10), 1160-1166.

62. Oyza, I., \& Edwin, A. M. (2016). Effectiveness of Social Media Networks as a Strategic Tool for Organizational Marketing Management. The Journal of Internet Banking and Commerce, 21, 1-17.

63. Paquette, H. (2013). Social Media as a Marketing Tool: A Literature Review. (Working paper). Rhode Island: University of Rhode Island.

64. Paridon, T. J. (2005). Antecedents in retail information sharing research: The case for personal shopping values and consumer self-confidence. Journal of Applied Management and Entrepreneurship, 10(4), 18.

65. Paridon, T. J. (2006). Extending and clarifying causal relationships in research involving personal shopping value, consumer self-confidence, and word of mouth communication. Marketing Management Journal, 16(1), 32-43.

66. Paridon, T. J., Carraher, S., \& Carraher, S. C. (2006). The income effect in personal shopping value, consumer self-confidence, and information sharing (word of mouth communication) research. Academy of Marketing Studies Journal, 10(2), 107.

67. Patino, A., Pitta, D. A., \& Quinones, R. (2012). Social media's emerging importance in market research. Journal of Consumer Marketing, 29(3), 233-237.

68. Pöyry, E., Parvinen, P., Salo, J., \& Blakaj, H. (2012). Hedonic and utilitarian search for electronic wordof-mouth. Paper presented at the System Science (HICSS), 45 th Hawaii International Conference.

69. Rahman, S. U., Saleem, S., Akhtar, S., Ali, T., \& Khan, M. A. (2014). Consumers' Adoption of Apparel Fashion: The Role of Innovativeness, Involvement, and Social Values. International Journal of Marketing Studies, 6(3), 49-64.

70. Ramlugun, V. G., \& Jugurnauth, L. (2014). The Scope of Social Media Browsing and Online Shopping for Mauritian E-Retailers: A Study Based on Utilitarian and Hedonic Values. Review of Integrative Business and Economics Research, 3(2), 219-241.

71. Rani, P. (2014). Factors influencing consumer behaviour. International Journal of Current Research and Academic Review, 2(9), 52-61.

72. Ravichandran, T., Deng, C., \& Huang, D. (2015). Effects of Managerial Response to E-WOM on Consumer Attitude. $36^{\text {th }}$ International Conference on Information Systems. Fort Worth.

73. Reza Jalilvand, M., \& Samiei, N. (2012). The effect of electronic word of mouth on brand image and purchase intention: An empirical study in the automobile industry in Iran. Marketing Intelligence \& Planning, 30(4), 460-476.

74. Rice, R. E., McCreadie, M., \& Chang, S. J. L. (2001). Accessing and browsing information and communication. Boston, MA: MIT Press. 
75. Ryu, K., Han, H., \& Jang, S. (2010). Relationships among hedonic and utilitarian values, satisfaction and behavioral intentions in the fast-casual restaurant industry. International Journal of Contemporary Hospitality Management, 22(3), 416-432.

76. Sandes, F. S., \& Urdan, A. T. (2013). Electronic word-of-mouth impacts on consumer behavior: Exploratory and experimental studies. Journal of International Consumer Marketing, 25(3), 181-197.

77. Satish, S., \& Bharadhwaj, S. (2010). Information search behaviour among new car buyers: A twostep cluster analysis. IIMB Management Review, 22(1), 5-15.

78. Shen, Y., Li, S., \& DeMoss, M. (2012). The effect of quantitative electronic word of mouth on consumer perceived product quality. International Journal of Management and Marketing Research, $5(2), 19-29$.

79. Singh, D. P. (2014). Online Shopping Motivations, Information Search, and Shopping Intentions in an Emerging Economy. The East Asian Journal of Business Management, 4(3), 5-12.

80. Siti, N. J., Pan, E. L., \& Mohaini, M. N. (2014). Consumers Perceptions, Attitudes and Purchase Intention towards Private Label Food Products in Malaysia. Asian Journal of Business and Management Sciences, 2(8), 74-78.

81. Stone, G. P. (1954). City shoppers and urban identification: observations on the social psychology of city life. American Journal of Sociology, 60, 36-45.

82. Suhr, D. D. (2006). Exploratory or confirmatory factor analysis?. Cary: SAS Institute.

83. Svatosová, V. (2013). Motivation of online buyer behavior. Journal of Competitiveness, 5(3), 14-30.

84. Teo, T. S. (2001). Demographic and motivation variables associated with Internet usage activities. Internet Research, 11(2), 125-137.

85. Thoumrungroje, A. (2014). The influence of social media intensity and EWOM on conspicuous consumption. Procedia-Social and Behavioral Sciences, 148, 7-15.

86. To, P-L., Liao, C., \& Lin, T-H. (2007). Shopping motivations on Internet: A study based on utilitarian and hedonic value. Technovation, 27(12), 774-787.

87. Tsimonis, G., \& Dimitriadis, S. (2014). Brand strategies in social media. Marketing Intelligence \& Planning, 32(3), 328-344.

88. Valentine, D. B., \& Powers, T. L. (2013). Online product search and purchase behavior of Generation Y. Atlantic Marketing Journal, 2(1), 122-144.

89. Vázquez-Casielles, R., Suárez-Álvarez, L., \& del Río-Lanza, A. B. (2013). The word of mouth dynamic: How positive (and negative) WOM drives purchase probability. Journal of Advertising Research, 53(1), 43-60.

90. Venkatesh, V., Morris, M. G., Davis, G. B., \& Davis, F. D. (2003). User acceptance of information technology: Toward a unified view. MIS quarterly, 27(3), 425-478.

91. Vineyard, C. L. (2014). The relationship between fashion blogs and intention to purchase and word of mouth behavior. Lincoln, NE: University of Nebraska.

92. Voyer, P. A., \& Ranaweera, C. (2015). The impact of word of mouth on service purchase decisions: examining risk and the interaction of tie strength and involvement. Journal of Service Theory and Practice, 25(5), 636-656.

93. Walsh, G., Gwinner, K. P., \& Swanson, S. R. (2004). What makes mavens tick? Exploring the motives of market mavens' initiation of information diffusion. Journal of Consumer Marketing, 21(2/3), 109-120.

94. Wang, X., Yu, C., \& Wei, Y. (2012). Social media peer communication and impacts on purchase intentions: A consumer socialization framework. Journal of Interactive Marketing, 26(4), 198-208.

95. Westbrook, R. A., \& Black, W. C. (1985). A motivation-based shopper typology. Journal of Retailing, 61(1), 78-103.

96. Wolfinbarger, M., \& Gilly, M. C. (2001). Shopping online for freedom, control, and fun. California Management Review, 43(2), 34-55. 